\section{SJESR}

Sir Syed Journal of Education \& Social Research

\title{
Three-dimensional Determinants of Job Stress among Pakistani School Teachers
}

\author{
* Syed Nasir Hussain, Lecturer \\ ** Asia Zulfqar, Assistant Professor \\ *** Uzma Shahzadi, Assistant Professor
}

\begin{abstract}
This study investigates the determinants of job stress among Pakistani school teachers. It was based upon influential stress models including job control, effort-reward imbalance and workplace resources. A sample of 297 teachers teaching at different levels in both public and private schools was selected by using cluster sampling technique. The sample covered a wide range of teachers with diverse backgrounds. A self-developed questionnaire consisting of 20 items was used to collect the data. A simple linear regression was applied to analyze the data. The study found that all three factors are significant determinants of job stress among Pakistani school teachers. Job demand-control accounts for 31\% of teachers' job stress; whereas $23 \%$ and $17 \%$ of job stress is due to job demands-resources and effort-reward imbalance respectively. When all these three factors were seen collectively, they constituted 40.5\% of teachers' job stress.
\end{abstract}

Keywords: Effort-Reward Imbalance, Job Demands-Control, Job Demands-Resources, Job stress, Pakistan School Teachers.

\section{Introduction}

Modernization of human life has brought unprecedented changes in individuals' personal and occupational lives e.g. job stress has become one of the crucial phenomena in the present-day occupational life. It has turned into a matter of great concern both for the employers and employees. Though multiple aspects of job stress like causes of stress, health issues, burnouts and turnovers, and stress coping strategies have been studied for the last five decades, yet the researchers are still searching for concrete conclusions. In the present-day scenario, an overwhelming majority of the employees is experiencing job-related stress. When this job stress increases from a certain limit, it starts posing threats to employee's performance, health and personal life, and resultantly whole working unit suffers.

\footnotetext{
* ECE \& Elementary Teacher Education Department, AIOU, Islamabad Email: nasirhussain99@gmail.com

** Department of Education, Bahauddin Zakariya University, Multan Email: asia.zulfqar@bzu.edu.pk

*** Department of Education, University of Sargodha, Sargodha Email: uzmashah_bzu@yahoo.com
} 
Job stress is a worldwide dilemma, and it is not restricted to a particular region or sector (Chan, Chen, \& Chong, 2010), and school teachers are no exception to it. The ever increasing and complex responsibilities of schools have put teachers under stress across the world. As far as the determinants of job stress are concerned, multiple factors have been identified. Majority of these determinants can be classified into three major categories - job latitude, balance between efforts and rewards, and the working environment i.e. employees suffer job stress when they feel that:

- Their control over the job is less-than-required to fulfill their job demands;

- Their efforts are greater than their rewards;

- Their work-place does not offer supportive physical, social and psychological settings.

These groups of determinants are well-defined and have been studied worldwide. Mostly, studies target one of the above-mentioned groups of determinants. Keeping in view that job stress is a result of multiple rather than one or two reasons, we designed this study to measure how much each determinant accounts for change in job stress among Pakistani school teachers.

\section{Literature Review}

\section{Job stress}

Stress is defined as organismic disequilibrium caused by some internal or external stimulant (Selye, 1978) which has excessive physical and psychological pressure on the individuals (Griffin, 1990). Stress is a response to a demanding situation for a person (Ratwant \& Jha, 2014). It is taken as the perception of a difference between job demands and individual capacities to fulfill these demands (Vermunt \& Steensma, 2005). Job stress badly affects the performance of the individuals and organizations. It results in low productivity (Khan et al., 2010), increased absenteeism along with drugs abuse and cardiovascular problems among the employees (Menze, 2005) and increased medical payments (Ali, Ishtiaq \& Ahmad, 2013).

Some well-defined stress models have also been developed in the literature. These models are being tested over long periods of time using credible research designs. Three of these stress models i.e. Job Demand-Control (J D-C) model, Effort-Reward Imbalance (ERI) model and Job Demand-Resources (J D-R) model are mostly acknowledged and used across the world (Schaufeli \& Taris, 2014).

The Job Demand-Control (JD-C) model assumes that job control or decision latitude is an important moderator of job stress (Karasek, 1979). It is considered as the most influential 
model of stress at the workplace (Kompier, 2003). As this model targets the structural features of an individual's interactions with the environment, it is classified as 'interactional model' (Cox \& Griffiths, 1995). The initial JD-C model used only decision latitude as the mediator (Karasek, 1979), but later social support was added to it (Johnson \& Hall, 1988). Due to frequently contradicted results of the studies based on the original model, the researchers preferred the expanded JD-C model (including social support) as a locus of control (Rodriguez, Bravo, Peiro, \& Schaufeli, 2001). The model is based upon the hypothesis that higher job control and better social support are the factors which reduce the negative effects of high job demands on employee's perceived level of stress.

Effort-reward imbalance (ERI) is another popular model of job stress. It is classified as 'transactional model' as it focuses upon subjective perceptions of the environment (Mark \& Smith, 2008). ERI model is based on the notion of 'social reciprocity', which claims that tasks are performed in exchange of rewards. These rewards include money, esteem, and career development opportunities. Lack of this reciprocity results in perceived 'high cost-low gain' situations. Furthermore, psychological reasons of being approved and esteemed at work lead to strive continuously for high achievements. This excessive work prompts overcommitment which may further increase perceived effort-reward imbalance (Siegrist, 2010).

Another influential model of job stress is Job Demand-Resource (JD-R) model extending its scope to employees' well-being which makes it more heuristic and overarching than J-DC and ERI models (Bakker \& Demerouti, 2007; Mark \& Smith, 2008). It considers characteristics of work environments for employee well-being. The model classifies work environment into two general categories i.e. job demands and job resources. Job demands refer to physical, social and organizational characteristics of job which require physiological and/or psychological efforts associated with physiological and/or psychological costs. While the job resources are those physical, social and organizational aspects of the job which helps in achieving work goals; reduce job demands and consequently the physiological and/or psychological costs (Demerouti at al., 2001).

\section{Job Stress among Teachers}

There are sufficient empirical evidences to support that teaching is one of the most stressful occupations (Johnson, et al., 2005). They found that teaching is amongst the worst professions regarding job stress. They further argued that the occupations involving emotional displays are likely to be more vulnerable to job stress than others. These emotions involve face to face or voice to voice interaction, influencing other peoples' behavior and 
attitude, and always following a certain set of rules. Teachers have to express all these emotional displays. When employees articulate emotions which are not part of their personality, lowered self-esteem and depression creeps in (Zafp, 2002). Multiple dimensions of teachers' job stress have been identified. Different studies have tried to identify factors causing job stress among teachers. Many of these studies have taken into account simple variables as job stressors (Chan, Chen \& Chong, 2010; Ekundayo \& Kolawole, 2013; Ravichandran \& Rajendran, 2007). Though all these studies have significantly contributed to understand teachers' job stress, yet stress dilemma is not as simple as it might look. Job stress has multiple socio-psychological determinants and, in most cases, requires going beyond the simplistic investigation of numerous stressors (Siegrist, 2010). We need well-defined concepts and theories which have been tested with convincing research designs. JD-C, ERI and JD-R are some of the well-defined theoretical frameworks of stress related studies across the occupations.

Job Demand-Control has been a widely used model in the studies focusing upon teachers' job stress (Brouwers, Tomic \& Boluijt, 2011; Pomaki \& Anagnostopoulou, 2003). It has been found that the teachers who have more job control perform better than the teachers who have less job control (Bradley, 2007).

In the same way, Effort-Reward Imbalance model has been used in many teachers' job stress studies (Kanel, Bellingrath \& Kudielka, 2009; Hussain, Hameed, Shah \& Aslam, 2016). The teachers who perceive that their efforts outweigh their rewards are more likely to suffer from stress than the teachers who perceive a balance between their efforts and rewards (Lehr, Hillert \& Keller, 2009). The perceived effort-reward imbalance has resulted in high risk of burnout symptoms and premature retirements (Unterbrink, et al., 2007). A strong association was also found between perceived ERI and adverse health outcomes amongst teachers (Bellingrath, Rohleder \& Kudielka, 2010).

Job Demand-Resources model has also been used as the framework in the studies regarding teachers' job stress (Bakker, Hakanen, Demerouti \& Xanthopoulou, 2007; Boyd, et al., 2011; Kakanen, Bakker \& Schaufeli, 2006). One of the major causes of stress is a situation where resources are not appropriate to cope with the demands and pressures of the job (Michie, 2002). The physical and psychological resources at schools support the teachers to handle job demands and minimize the chances of job stress among teachers (Arnold et al., 2007). The negative effects of job stress are reduced when educational institutions have better physical resources (Betoret, 2006). Apart from the physical resources, human resource 
support can also curtail job stress. Social support from the headteachers and colleagues has been found as a strong moderator for job stress and its impacts (Russel, Altimaier \& Velzen, 1987).

Though all three stress models have their own strengths and weaknesses yet JD-C, ERI and JD-R models are currently recognized as the leading stress models used by the researchers (Schaufeli \& Taris, 2014). The researchers have used any one of these theoretical models to find out causes of stress across the occupations. Our study is an attempt to integrate all three models in one study and trace out how much each factor accounts for teachers' job stress in Pakistan.

\section{Research Questions}

- What is the perceived level of stress among teachers of public and private schools?

- What are the key determinants of job stress among teachers of public and private schools?

- What is the relationship between J D-C, ERI and J D-R with job stress among teachers of public and private schools?

\section{Research Methodology}

Job stress is a widely researched phenomenon across the occupations. Several studies are available which have used quantitative research design to identify job stressors, and then findings were generalized. This study also followed the quantitative research design based on survey. A self-developed questionnaire was used to collect the data. The population of the study consisted of all teachers of government and private secondary schools in Punjab. The accessible population consisted on the teachers from two districts (Lahore and Sargodha) of the Punjab province. Cluster sampling technique was used to select a sample of 297 school teachers from both the public and private sector.

The questionnaire was developed and distributed into four parts. To keep the questionnaire short and tidy, every part consisted of 5 items each. Thus, the scale consisted of 20 statements based on a five-point Likert scale. In the first three parts, the determinants of teachers' job stress were identified on three different factors i.e. job control, perceived effortreward imbalance and job resources.

In the fourth part, level of job stress was measured. Five statements on five-point Likert scale were used to measure the job stress. So, the range of scores was from 5 to 25 . Following the categorization of stress level used in Stress in General (SIG) Scale - a standardized scale, the respondents with scores less than 8 were categorized as 'no stress at all', while the 
teachers with a score of 8-12, 13-17, 18-22 and above 22 respectively were categorized with a 'low', 'moderate', 'high' and 'very high' level of job stress.

The questionnaire was pilot tested on 80 teachers. The Cronbach alpha reliability coefficients for each part were $0.617,0.680,0.609$ and 0.713 respectively for JDC, ERI, JDC and level of stress. While the value of Cronbach alpha for the whole scale was 0.852 .

Apart from the descriptive statistics, a simple linear regression model was used to measure the impact of individual factors of stressors on the job stress of school teachers. All the statistical calculations were made using SPSS 22.

\section{Findings}

Table 1. Demographical distribution of the respondents

\begin{tabular}{|c|c|c|}
\hline Variable & Classification & No. of respondents \\
\hline \multirow{2}{*}{ Gender } & Male & 147 \\
\hline & Female & 150 \\
\hline \multirow{2}{*}{ Locality } & Urban & 214 \\
\hline & Rural & 83 \\
\hline \multirow{4}{*}{ Marital status } & Single & 78 \\
\hline & Married & 198 \\
\hline & Divorced / & 21 \\
\hline & Widow(er) & \\
\hline \multirow{2}{*}{ Sector } & Government & 229 \\
\hline & Private & 68 \\
\hline \multirow[t]{2}{*}{ Job status } & Permanent & 185 \\
\hline & Temporary / Contract & 112 \\
\hline \multirow[t]{3}{*}{ Classes } & Primary & 46 \\
\hline & Elementary & 137 \\
\hline & High & 114 \\
\hline Academic & Under graduation & 6 \\
\hline \multirow[t]{3}{*}{ qualification } & Graduation & 51 \\
\hline & Masters & 192 \\
\hline & MPhil / PhD & 48 \\
\hline \multirow[t]{4}{*}{ Job experience } & Less than 2 years & 47 \\
\hline & $2-5$ years & 75 \\
\hline & $6-10$ years & 51 \\
\hline & More than 10 years & 124 \\
\hline Number of dependents & 3 or less & 117 \\
\hline
\end{tabular}




\begin{tabular}{llc} 
& $4-6$ & 133 \\
& More than 6 & 47 \\
\hline Workload (No. of & 20 or less & 30 \\
periods per week) & $21-40$ & 223 \\
& More than 40 & 44 \\
\hline Distance travelled & 15 or less & 188 \\
(daily one sided in & $16-40$ & 66 \\
KMs) & More than 40 & 43 \\
\hline Take home monthly & Less than 30,000 & 85 \\
salary (in PKR) & $30,000-50,000$ & 139 \\
& More than 50,000 & 73 \\
\hline
\end{tabular}

Table 1 shows that teachers with diverse backgrounds were involved in the study. Teachers with almost every background were ensured to be part of the sample. The sample was distributed on the bases of gender, locality, marital status, sector, job status, grades to teach, academic qualification, job experience, number of dependents, workload, distance to be traveled daily, and take-home monthly salary. A significant number of teachers represented each classification of these demographical variables.

Table 2. Level of stress

\begin{tabular}{lcc}
\hline \multicolumn{1}{c}{ Stress Level } & Frequency & Percent \\
\hline Not at all & 6 & 2.0 \\
Low & 64 & 21.5 \\
Moderate & 160 & 53.9 \\
High & 55 & 18.5 \\
Very High & 12 & 4.0 \\
\hline
\end{tabular}

Table 2 shows the level of stress measured among the teachers. It was found that only $2 \%$ of the respondents reported no stress at all while $21.5 \%$ of the respondents told that they are facing a low level of job stress. Majority of the teachers (53.9\%) reported the moderate level of stress while $22.5 \%$ of the responding teachers were facing a high or very high level of stress.

Table 3. Linear regression model for JDC

\section{Model Summary}

\begin{tabular}{cccccc}
\hline Model & $\mathrm{R}$ & $\mathrm{R}^{2}$ & Adjusted $^{2}$ & $\begin{array}{c}\text { Std. Error of the } \\
\text { Estimate }\end{array}$ & $\begin{array}{c}\text { Durbin- } \\
\text { Watson }\end{array}$ \\
\hline 1 & $.55^{\mathrm{a}}$ & .31 & .31 & 3.11 & 2.04 \\
\hline
\end{tabular}

a. Predictors: (Constant), JDC 
ANOVA $^{\mathrm{a}}$

\begin{tabular}{llccccc}
\hline \multirow{2}{*}{ Model } & Sum of & $d f$ & Mean Square & F & Sig. \\
& & Squares & & & & \\
\hline \multirow{3}{*}{1} & Regression & 1008.00 & 5 & 201.60 & 20.778 & $.00^{\mathrm{b}}$ \\
& Residual & 2823.51 & 291 & 9.70 & & \\
& Total & 3831.51 & 296 & & & \\
\hline
\end{tabular}

a. Dependent Variable: Stress

b. Predictors: (Constant), JDC

\section{Coefficients $^{\mathrm{a}}$}

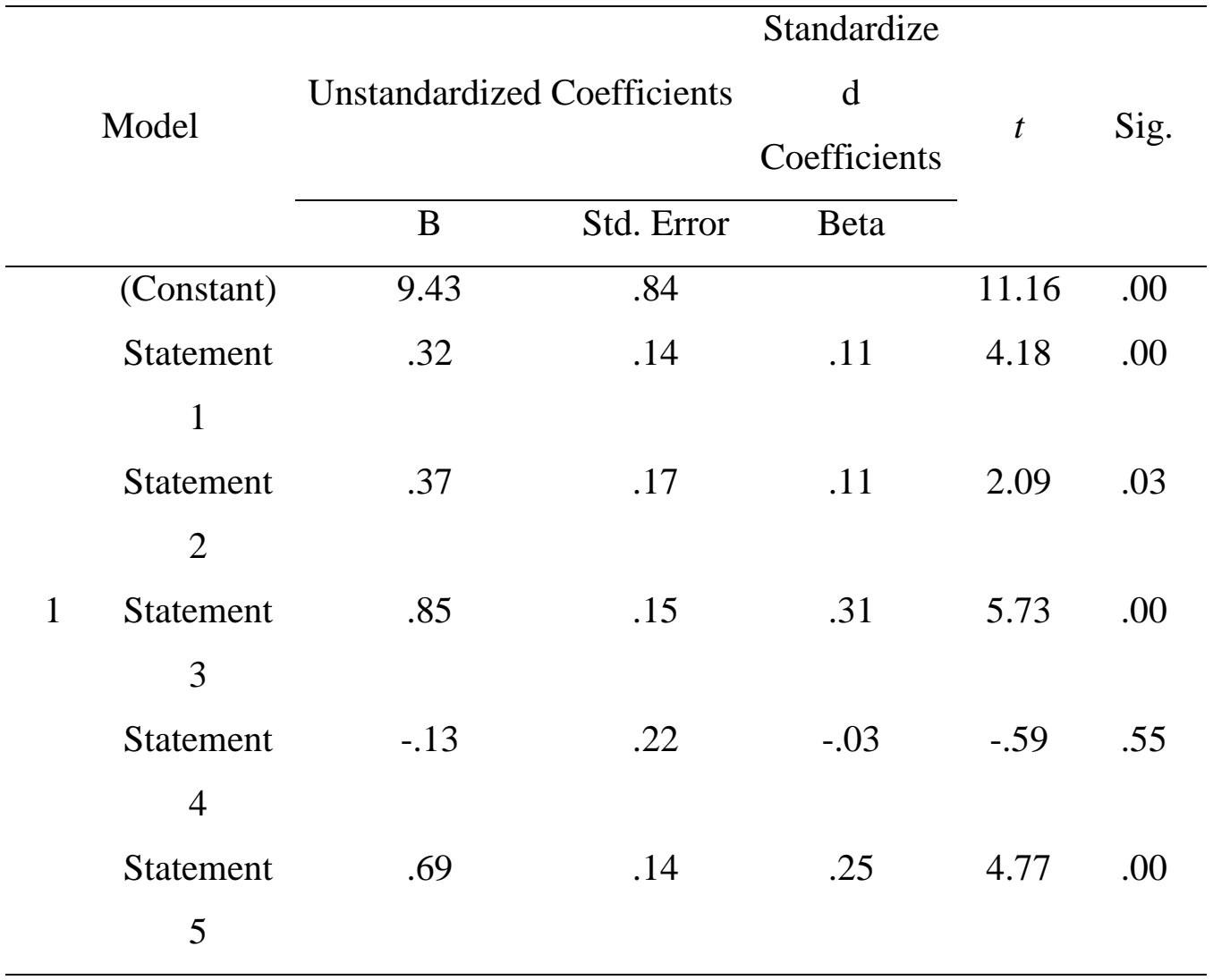

a. Dependent Variable: Stress

The coefficient of correlation between JDC and stress was $0.559(\mathrm{R}=0.559) . \mathrm{R}^{2}$ shows that JDC accounts for $31.3 \%$ of the job stress among teachers. As the value of Durbin-Watson (2.045) is very close to 2, the residual of all the statements in JDC are uncorrelated. This uncorrelated residual permits us to generalize our findings to the whole population. As the value of $\mathrm{F}(20.778)$ is significant at $p<0.001$, ANOVA on the linear model testifies that this model best suited our data and predicts the stress level of the teachers very well. The coefficients show that job stress of the teachers is due to their perceptions that they 
unnecessarily have to follow rules and regulation which can easily be avoided $(t=4.182, p<$ 0.001); their colleagues and superiors do not support their actions and decisions $(t=2.091, p$ $<0.05)$; they have to do things on the job that are against my better judgment $(t=5.731, p<$ $0.001)$; and they always feel time pressure to fulfill my assignments in time $(t=4.778, p<$ $0.001)$.

Table 4. Linear regression model for ERI

Model Summary

\begin{tabular}{cccccc}
\hline Model & $\mathrm{R}$ & $\mathrm{R}^{2}$ & $\begin{array}{c}\text { Adjusted } \\
\mathrm{R}^{2}\end{array}$ & $\begin{array}{c}\text { Std. Error of the } \\
\text { Estimate }\end{array}$ & $\begin{array}{c}\text { Durbin- } \\
\text { Watson }\end{array}$ \\
\hline 1 & $.41^{\mathrm{a}}$ & .16 & .15 & 3.40 & 1.98
\end{tabular}

a. Predictors: (Constant), ERI

ANOVA $^{\mathrm{a}}$

\begin{tabular}{clccccc}
\hline Model & & Sum of & $d f$ & Mean Square & F & Sig. \\
& & Squares & & & & \\
\hline \multirow{3}{*}{1} & Regression & 453.22 & 5 & 90.64 & 7.80 & $.00^{\mathrm{b}}$ \\
& Residual & 3378.28 & 291 & 11.60 & & \\
& Total & 3831.51 & 296 & & & \\
\hline
\end{tabular}

a. Dependent Variable: Stress

b. Predictors: (Constant), ERI

Coefficients $^{\mathrm{a}}$

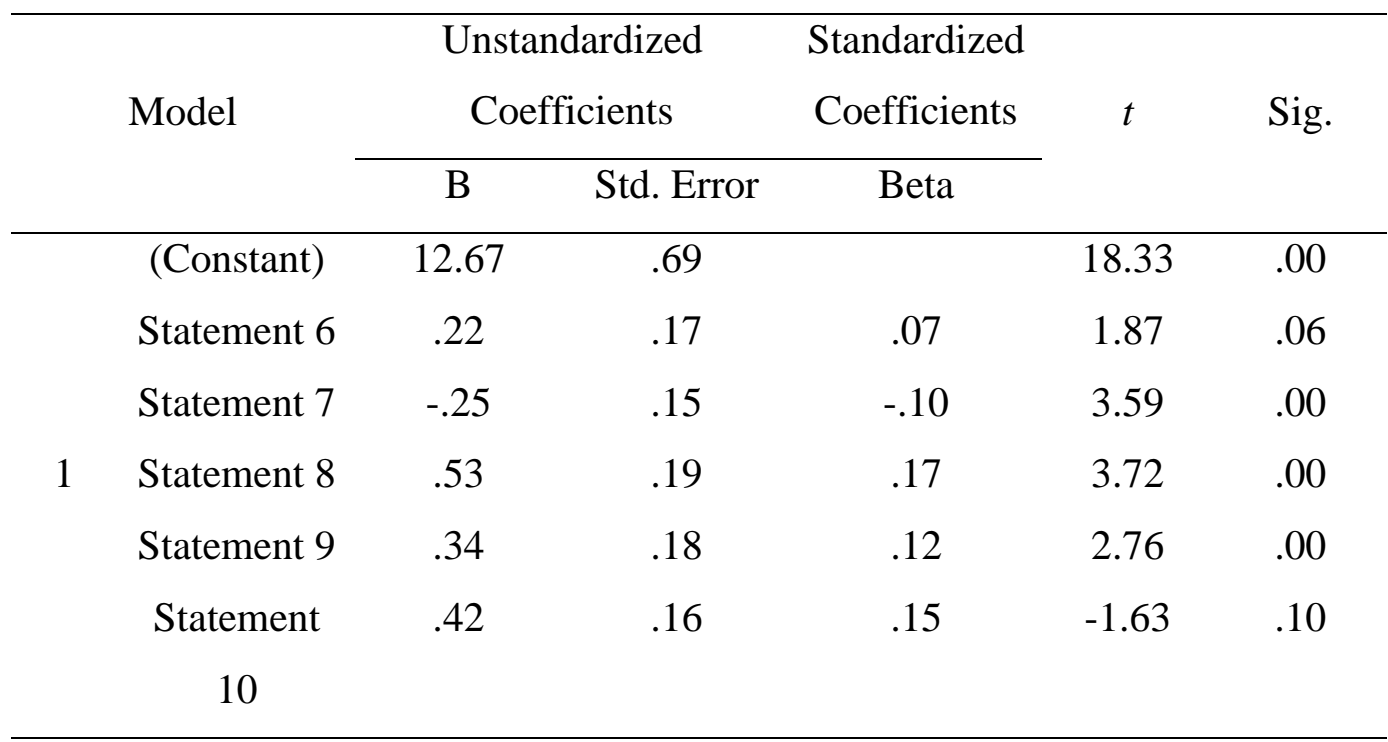

a. Dependent Variable: Stress 
The coefficient of correlation between ERI and stress was $0.410(\mathrm{R}=0.410)$. ERI accounts for $16.8 \%$ of the job stress among teachers $\left(\mathrm{R}^{2}=0.168\right)$. The value of Durbin-Watson $(1.987)$ warrants us to generalize our results to the whole population (being very close to 2). Furthermore, $\mathrm{F}$ value for ANOVA (7.808) is significant at $p<0.001$, which concludes that the model used is best suited our data and will be a suitable predictor of teachers' job stress. The coefficients of stress show that teachers feel stress because they sense that their current position is not according to their education and training $(t=3.590, p<0.001)$; they do not receive prestige and respect they deserve at work $(t=3.728, p<0.001)$; and their promotion prospects are not in accordance with their efforts at work $(t=2.767, p<0.01)$.

Table 5. Linear regression model for JDR

\section{Model Summary}

\begin{tabular}{|c|c|c|c|c|c|}
\hline Model & $\mathrm{R}$ & $\mathrm{R}^{2}$ & Adjusted $\mathrm{R}^{2}$ & Std. Error of the Estimate & $\begin{array}{l}\text { Durbin- } \\
\text { Watson }\end{array}$ \\
\hline 1 & $.48^{\mathrm{a}}$ & .23 & .23 & 3.28 & 1.94 \\
\hline
\end{tabular}

a. Predictors: (Constant), JDR

\begin{tabular}{ccccccc}
\multicolumn{7}{c}{ ANOVA $^{\text {a }}$} \\
\hline \multirow{2}{*}{ Model } & Sum of & $d f$ & Mean Square & F & Sig. \\
& Squares & & & & \\
\hline \multirow{2}{*}{1} & Regression & 696.69 & 5 & 139.33 & 12.93 & $.00^{\text {b }}$ \\
& Residual & 3134.82 & 291 & 10.77 & & \\
& Total & 3831.51 & 296 & & &
\end{tabular}
a. Dependent Variable: Stress
b. Predictors: (Constant), JDR

Coefficients $^{\text {a }}$

\begin{tabular}{|c|c|c|c|c|c|c|}
\hline & \multirow{3}{*}{ Model } & \multirow{2}{*}{\multicolumn{2}{|c|}{$\begin{array}{c}\text { Unstandardized } \\
\text { Coefficients }\end{array}$}} & \multirow{3}{*}{$\begin{array}{c}\text { Standardized } \\
\text { Coefficients }\end{array}$} & \multirow{3}{*}{$t$} & \multirow{3}{*}{ Sig. } \\
\hline & & & & & & \\
\hline & & B & Std. Error & & & \\
\hline \multirow{5}{*}{1} & (Constant) & 10.43 & .85 & & 12.24 & .00 \\
\hline & Statement & .59 & .17 & .20 & 3.38 & .00 \\
\hline & 11 & & & & & \\
\hline & Statement & .86 & .17 & .28 & 4.87 & .00 \\
\hline & 12 & & & & & \\
\hline
\end{tabular}




$\begin{array}{cccccc}\begin{array}{c}\text { Statement } \\ 13\end{array} & .18 & .18 & .05 & 1.99 & .02 \\ \text { Statement } & .17 & .21 & .05 & .81 & .41 \\ 14 & & & & & \\ \text { Statement } & -.04 & .22 & -.01 & -.17 & .86 \\ 15 & & & & & \end{array}$

a. Dependent Variable: Stress

As far as JDR was concerned, the coefficient of correlation between JDR and stress was $0.482(\mathrm{R}=0.482)$ while JDR explains $23.2 \%$ of teachers' job stress. In this case, also, the value of Durbin-Watson (1.943) authorizes us to generalize the findings back to our population. F (12.935) is found to be significant at $p<0.001$, which tells us that the model used was the best fit on our data and properly predicts the stress level of the teachers. The coefficients show that job stress of the teachers is due to their feelings regarding heavy workload $(t=3.382, p<0.01)$; exhaustion as they have to remain physically and mentally alert all the time $(t=4.847, p<0.001)$; and perception that they are not included in decisionmaking process especially when these decisions are going to affect them $(t=1.997, p<0.05)$.

Table 6. Linear regression model for JDC, ERI and JDR collectively

\section{Model Summary}

\begin{tabular}{cccccc}
\hline Model & $\mathrm{R}$ & $\mathrm{R}^{2}$ & Adjusted $\mathrm{R}^{2}$ & $\begin{array}{c}\text { Std. Error of the } \\
\text { Estimate }\end{array}$ & $\begin{array}{c}\text { Durbin- } \\
\text { Watson }\end{array}$ \\
\hline 1 & $.63^{\mathrm{a}}$ & .40 & .39 & 3.12 & 1.98 \\
\hline
\end{tabular}

a. Predictors: (Constant), JDC, ERI, JDR

\begin{tabular}{ccccccc}
\multicolumn{7}{c}{ ANOVA $^{\text {a }}$} \\
\hline \multirow{2}{*}{ Model } & Sum of & $d f$ & Mean Square & F & Sig. \\
& & Squares & & & & \\
\hline & Regression & 978.39 & 3 & 326.13 & 33.49 & $.00^{\mathrm{b}}$ \\
1 & Residual & 2853.12 & 293 & 9.73 & & \\
& Total & 3831.51 & 296 & & &
\end{tabular}

a. Dependent Variable: Stress

b. Predictors: (Constant), JDC, ERI, JDR 


\begin{tabular}{|c|c|c|c|c|c|}
\hline \multicolumn{6}{|c|}{ Coefficients $^{\mathrm{a}}$} \\
\hline \multirow{3}{*}{ Model } & \multirow{2}{*}{\multicolumn{2}{|c|}{$\begin{array}{c}\text { Unstandardized } \\
\text { Coefficients }\end{array}$}} & \multirow{3}{*}{$\begin{array}{c}\text { Standardized } \\
\text { Coefficients } \\
\text { Beta }\end{array}$} & \multirow{3}{*}{$t$} & \multirow{3}{*}{ Sig } \\
\hline & & & & & \\
\hline & B & Std. Error & & & \\
\hline (Constant) & 6.52 & .99 & & 6.58 & .00 \\
\hline JDC & .44 & .06 & .37 & 6.88 & .00 \\
\hline ERI & .09 & .04 & .11 & 2.53 & .01 \\
\hline JDR & .16 & .06 & .15 & 2.67 & .00 \\
\hline
\end{tabular}

a. Dependent Variable: Stress

The collective prediction of JDC, ERI and JDR regarding teachers' job stress was calculated. It was found that collectively JDC, ERI and JDR accounts for $40.5 \%$ of the job stress among teachers $\left(\mathrm{R}^{2}=0.405\right)$. The value of Durbin-Watson $(1.984)$ warrants us to generalize our results to the whole population. Furthermore, F value for ANOVA (33.492) is significant at $p$ $<0.001$, which concludes that the model used best suited our data and is a suitable predictor of teachers' job stress. The coefficients of the model show the slope of all three factors i.e. JDC, ERI and JDR is not zero $(t=6.884, t=2.533$ and $t=2.673$ respectively $)$ and all three factors are good determinants of the teachers' job stress.

\section{Discussion}

Majority of the school teachers in Punjab are experiencing job stress. Earlier studies also found that teachers from primary school level (Hanif, Tariq, \& Nadeem, 2011) to university level in Pakistan are facing a high level of job stress (Usman et al., 2011). Numerous studies have been conducted to find out the causes of job stress among teachers in Pakistan, but little work has been done keeping in view the stress models i.e. J D-C, ERI and J D-R.

This study found that keeping in view job demands of the teachers, they feel that they do not have desired control over their job affairs. This lack of desired control over job accounts for $31 \%$ of teachers' job stress. The decision making in Education sector in Punjab is overly centralized (World Bank, 2005) which has shaped the perception of the teachers that they have little control over their job, and the rules and policies are imposed upon them.

The study found that teachers perceive an imbalance between their efforts and rewards. This perceived imbalance between effort and reward accounts for $17 \%$ of teachers' job stress. This figure is very close to the findings of an earlier study which found that ERI accounts for $20 \%$ of teachers' job stress of Pakistani school teachers (Hussain etal., 2016). It is interesting to note that teachers did not show concerns with their job security and salary. Their major 
concerns were that their position is not according to their education or training, low prestige at the workplace and inadequate promotion prospects.

According to this study, teachers feel that job resources are less than their job demands which account for $23 \%$ of their job stress. They perceive that their workload is too heavy and all the time they have to remain mentally and physically alert which exhausts them. After many studies in diverse contexts and different parts of the world, sufficient empirical evidence are available to conclude that when workers are supposed to display emotions throughout their working hours, they are more prone to suffer job stress, and teaching is one of those professions (Johnson, et al., 2005).

This study also found that most influential and worldwide recognized stress model i.e. $\mathbf{J}$ D-C, ERI and J D-R could only account for $40.5 \%$ of the teachers' job stress in the context of Punjab (Pakistan). Still, around $60 \%$ of the teachers' job stress remained unexplained. The possible reasons for this high amount of unidentified job stress might be the prevalent negative perceptions among school teachers regarding strict monitoring, unrealistic targets to be achieved, unjustified accountability, and heavy paperwork. As the local working conditions and demands were hugely different from many contexts and were out of the scope of this study, we were unable to find an enhanced list of determinants of job stress of Pakistani school teachers.

\section{Conclusions}

The study concludes that majority of the Pakistani school teachers are facing job stress. A major portion of this stress is due to their feelings that they do not have the desired level of control on their job. At times, they have to follow rules and regulation unnecessarily and execute in a manner which is against their good judgment. In addition, they believe that their efforts are higher than their rewards. They feel that they do not get due respect and prestige at the workplace. The teachers perceive that neither are their promotion prospects adequate nor their current position is in accordance with their education and training. Furthermore, the social and psychological resources are not according to the demands of their job. They reported a heavy workload which exhausts them because they have to remain physically and mentally alert all the time during teaching. They also feel that they are not included in the decision-making process rather decisions are imposed upon them. So, it can be concluded that a significant portion of teachers' job stress is due to less control over their job, perceived effort-reward imbalance and inadequate resources comparing their job demands.

\section{Recommendations}


On the basis of the findings of the study, it is recommended that:

- Decision making should be delegated to grass-root level with the flexibility of implementation at the end of the teachers.

- A more appropriate promotion policy and qualification-based mechanism should be used to reduce job stress among teachers.

- Further studies focusing on the local contextual factors which were beyond the scope of this study should be conducted.

\section{References}

Ali, K., Ishtiaq, I., \& Ahmad, M. (2013). Occupational stress effects and job performance in the teachers of schools of Punjab (Pakistan). International Journal of Academic Research in Business and Social Sciences, 3(11), 665-680.

Arnold, B., Jari, H., Evangelia, E., \& Despoina. (2007). Job stress boost work engagement, particularly when job demands are high. Journal of Educational Psychology, 99(2), 274-284.

Bakker, A. B., \& Demerouti, E. (2007). The Job Demands-Resources Model: State of the Art. Journal of Managerial Psychology, 22(3), 309-328.

Bakker, A. B., Hakanen, J. J., Demerouti, E., \& Xanthopoulou, D. (2007). Job Resources Boost Work Engagement particularly when Job Demands are High. Journal of Educational Psychology, 99, 274-284.

World Bank. (2005). Education sector adjustment credit for the Government of Punjab province. Bangkok: World Bank. Retrieved from http://www-wds.worldbank.org/ external/default/WDSContentServer/WDSP/IB/2005/04/08/000090341_20050408084 910/Rendered/PDF/31750.pdf

Bellingrath, S., Rohleder, N., \& Kudielka, B. M. (2010). Healthy Working School Teachers with High Effort-Reward Imbalance and Overcommitment Show Increased proInflammatory Immune Activity and a Dampened Innate Immune Defence. Brain, Behavior, and Immunity, 24, 1332-1339.

Betoret, F. D. (2006). Stressors, self- efficacy, coping resources and burnout among secondary school teachers in Spain. Educational Psychology, 26(4), 519-539.

Boyd, C. M., Bakker, A. B., Pignata, S., Winefield, A. H., Gillespie, N., \& Stough, C. (2011). A Longitudinal Test of the Job Demands-Resources Model among Australian University Academics. Applied Psychology: An International Review, 60, 112-140. 
Bradley, G. (2007). Job tenure as a moderator of stressor-strain relations: A comparison of experienced and new-start teachers. Work and Stress, 21(1), 48-64.

Brouwers, A., Tomic, W., \& Boluijt, H. (2011). Job Demands, Job Control, Social Support and Self-Efficacy Beliefs as Determinants of Burnout among Physical Education Teachers. Europe's Journal of Psychology, 1, 17-39.

Chan, A. H., Chen, K., \& Chong, Y. L. (2010). Work Stress of Teachers from Primary and Secondary Schools in Hong Kong. International MultiConference of Engineers and Computer Scientists. III. Hong Kong: IMECS.

Cox, T., \& Griffiths, A. (1995). The Nature and Measurement of Work Stress: Theory and Practice. In J. R. Wilson, \& E. N. Corlett, Evaluation of Human Work: A Practical Ergonomics Methodology. London: Taylor \& Francis.

Demerouti, E., Bakker, A. B., Nachreiner, F., \& Schaufeli, W. B. (2001). The Job DemandsResources Model of Burnout. Journal of Applied Psychology, 86, 499-512.

Ekundayo, H. T., \& Kolawole, A. O. (2013). Stress among Secondary School Teachers in Ekiti State, Nigeria. Journal of Educational and Social Research, 3(2), 311-315.

Griffin, R. W. (1990). Management (3rd ed.). Boston: Houghton Mifflin Co.

Hanif, R., Tariq, S., \& Nadeem, M. (2011). Personal and Job-Related Predictors of Teacher Stress and Job Performance among School Teachers. Pakistan Journal of Commerce and Social Sciences, V(2), 319-329.

Hussain, S. N., Hameed, A., Shah, Z. A., \& Aslam, M. M. (2016). Understanding relationship between Effort-Reward Imbalance and job stress: An evidence from Pakistani Schools. PONTE, 72(4).

Johnson, J. V., \& Hall, E. M. (1988). Job strain, workplace social support, and cardiovascular disease: A cross-sectional study of a random sample of the Swedish working population. American Journal of Public Health, 78, 1336-1342.

Johnson, S., Cooper, C., Cartwright, S., Donal, I., Taylor, P., \& Millet, C. (2005). Observation piece: The experience of work-related stress across occupations. Journal of Managerial Psychology, 20(2), 178-187.

Kakanen, J., Bakker, A. B., \& Schaufeli, W. B. (2006). Burnout and Work Engagement among Teachers. Journal of School Psychology, 43, 495-513.

Kanel, R., Bellingrath, S., \& Kudielka, B. M. (2009). Overcommitment but not EffortReward Imbalance Relates to Stress-Induced Coagulation Changes in Teachers. Annals of Behavioral Medicine, 37, 20-28. 
Karasek, R. A. (1979). Job Demands, Job Decision Latitude and Mental Strain. Implications for Job Redesign. Administrative Science Quaterly, 24, 285-308.

Khan, A., Shah, I. M., Khan, S., \& Gul, S. (2010). Teachers' Stress, performance, and Resources: The Moderating Effects of Resources on Stress and Performance. International Review of Social Sciences and Humanities, 2(2), 21-29.

Kompier, M. (2003). Job Design and Well-being. In M. Schabracq, J. Winnubst, \& C. L. Cooper, Handbook of Work and Health Psychology (pp. 429-454).

Lehr, D., Hillert, A., \& Keller, S. (2009). What can balance the effort? Associations between Effort-Reward Imbalance. Overcommitment, and Affective Disorders in German teachers. International Journal of Occupational and Environmental Health, 15, 374384.

Mark, G. M., \& Smith, A. P. (2008). Stress Models: A Review and Suggested New Direction. In J. Houdmont, \& S. Leka, EA-OHP Series (Vol. 3, pp. 111-144). Nottingham: Nottingham University Press.

Menze, M. N. (2005). The impact of stress on productivity of employees at the education training and development practices: Sector education and training authority. University of Pretoria: Department of Social Work and Criminology.

Michie, S. (2002). Causes and management of stress at work. Occupational and Environmental Medicine, 59, 67-72.

Pomaki, G., \& Anagnostopoulou, T. (2003). A test and extension of the demand/control/social support model: Prediction of wellness/health outcomes in Greek teachers. Psychology and Health, 18(4), 537-550.

Ratwant, R. G., \& Jha, P. C. (2014). Impact of job-related stress on employee performance: IOSR Journal of Business and Management, 16(11), 1-6.

Ravichandran, R., \& Rajendran, R. (2007). Perceived sources of stress among the teachers. Journal of Indian Academy of Applied Psychology, 33(1), 133-136.

Rodriguez, I., Bravo, M. J., Peiro, J. M., \& Schaufeli, W. (2001). The Demands-ControlSupport model, Locus of Control and Job Dissatisfaction: A Longitudinal Study. Work and Stress, 15(2), 97-114.

Russel, D., Altimaier, E., \& Velzen, V. (1987). Job-related stress, social support, and burnout among classroom teachers. Journal of Applied Psychology, 72(2), 269-274.

Schaufeli, W. B., \& Taris, T. W. (2014). A Critical Review of the Job Demand-Resources Model: Implications for Improving Work and Health. In G. F. Bauer, \& O. Hammig, 
Bridging Occupational, Organizational and Public Health: A Transdisciplinary Approach (pp. 43-68). Dordrecht: Springer.

Selye, H. (1978). The Stress of Life (revised ed.). New York: McGraw-Hill.

Siegrist, J. (2010). Effort-reward imbalance at work and cardiovascular diseased. International Journal of Occupational Medicine and Environmental Health, 23(3), 279-285.

Unterbrink, T., Hack, A., Pfeifer, R., Buhl-GrieBhaber, V., Muller, U., Wesche, H., Bauer, J. (2007). Burnout and effort-reward-imbalance in a sample of 949 German teachers. Int Arch Occup Environ Health, 80, 433-441.

Usman, A., Ahmed, D. Z., Ahmed, I., \& Akbar, Z. (2011). Work stress experienced by the teaching staff of University of Punjab, Pakistan: Antecedents and consequences. International Journal of Business and Social Sciences, 2(8), 202-210.

Vermunt, R., \& Steensma, H. (2005). How can justice be used to manage stress in organizations? Handbook of organizational justice, 383-410.

Zafp, D. (2002). Emotion work and psychological well-being: A review of the literature and some conceptual considerations. Human Resource Management Review, 12, 1-32. 